\title{
Grounding Trademark Law Through Trademark Use ${ }^{\dagger}$
}

\author{
Stacey L. Dogan ${ }^{*} \mathcal{E}$ Mark A. Lemley ${ }^{* *}$
}

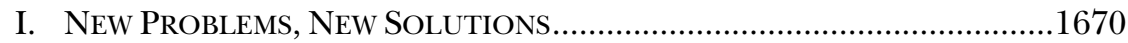

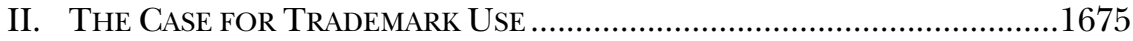

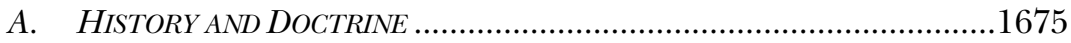

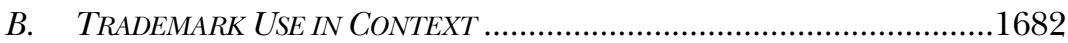

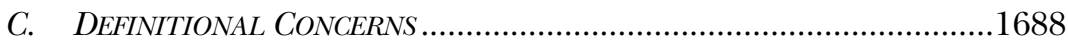

III. Policy Reasons For Maintaining the Direct/Indirect

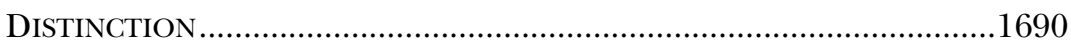

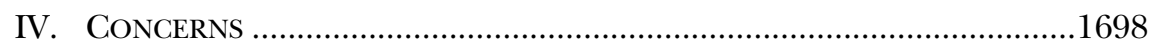

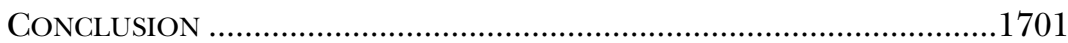

$\dagger$ (C) 2007 Stacey L. Dogan and Mark A. Lemley.

* Professor of Law, Northeastern University School of Law

** William H. Neukom Professor of Law, Stanford Law School; Of Counsel, Keker \& Van Nest LLP.

Thanks to Eric Kaviar for excellent research assistance and to Margreth Barrett, Eric Goldman, Wendy Gordon, Rose Hagan, Jessica Litman, David McGowan, Mark McKenna, Lisa Ramsey, and Rebecca Tushnet for comments on an earlier draft. Readers may wish to know, in the interest of full disclosure, that Mark Lemley represents Google in several ongoing cases involving keyword advertising. The views we express in this Article are our own and are not attributable to Google (or to anyone else, for that matter). 
The debate over "trademark use" has become a hot-button issue in intellectual property ("IP") law. In Confusion over Use: Contextualism in Trademark Law, Graeme Dinwoodie and Mark Janis characterize it as a dispute over whether to limit trademark-holder rights in a new and unanticipated way. ${ }^{1}$ Yet, there is another-and in our view more historically accurate-way to frame the trademark use debate: the question is whether courts should, absent specific statutory authorization, allow trademark holders to assert a new and unprecedented form of trademark infringement claim. The pop-up and keyword cases involve attempts to impose third-party liability under the guise of direct infringement suits. ${ }^{2}$ Dinwoodie and Janis's thorough account notwithstanding, it remains a fact that, before the recent spate of Internet-related cases, no court had ever recognized a trademark claim of the sort that trademark holders are now asserting. Trademark infringement suits have always involved allegations of infringement by parties who use marks in connection with the promotion of their own goods and services. ${ }^{3}$ The question raised by the trademark use cases, as we view it, is whether courts should countenance a radical departure from that traditional model without specific instruction from Congress. We think they should not.

\section{New Problems, NeW SOlutions}

Trademark law has come a long way. It surfaced, centuries ago, as a guardian of traders who used "marks," or symbols, to indicate the source of their wares and who wished to prevent competitors from using the same mark to deceive customers into buying the wrong product. Over time, trademark law grew to accommodate changes in the nature of commerce and the norms of marketing and advertising. The law now protects a broad array of devices-including shapes, colors, sounds, and smells-against use not only by competitors but also by sellers of even peripherally related products. And the doctrine of consumer confusion-which, as Professors Dinwoodie and Janis point out, has served as the "touchstone for trademark liability" in recent years ${ }^{4}$-has allowed the expansion of trademark-owner

1. Graeme B. Dinwoodie \& Mark D. Janis, Confusion over Use: Contextualism in Trademark Law, 92 IOWA L. REV. 1597 (2007).

2. See infra note 62 (listing the pop-up and keyword cases).

3. An exception-contributory infringement—applies only when a defendant actively induces another party's infringement or "continues to supply its product to one whom it knows or has reason to know is engaging in trademark infringement." Inwood Labs., Inc. v. Ives Labs., Inc., 456 U.S. 844, 854 (1982). But even in that case, the claim is premised on an act of direct infringement by someone who is using the mark in connection with her goods or services. In other words, if there is no direct infringer making a trademark use, there is no infringement to which to contribute.

4. Dinwoodie \& Janis, supra note 1, at 1599. For an interesting historical analysis suggesting that unfair competition, rather than consumer confusion, motivated trademark law 
rights as well, to the point where the law prevents not only passing off, but any use that might create an association between the trademark holder and the defendant's product or service.

This steady expansion in the subject matter and scope of trademark law has not gone unnoticed, and legal scholars have long sounded warnings about the dangers of overly muscular trademark rights. ${ }^{6}$ But in the last several years, the nature of the debate has changed. The growth of the Internet has revolutionized the ways in which people obtain information about their world, including products and services sold under trademarks. Increasingly, consumers identify, research, and purchase goods exclusively online, often with the assistance of Internet intermediaries. ${ }^{7}$ These intermediaries use all of the linguistic and technological tools at their disposal to disseminate relevant information, including advertisements, to their clients. Sometimes they match advertisers with clients based on preferences revealed by the clients' use of a protected trademark. ${ }^{8}$ And increasingly, these intermediaries are facing trademark claims based on such "use" of protected marks.

It is no accident that the rise of these Internet-based trademark claims has occasioned a re-examination of the core principles of trademark law. As Dinwoodie and Janis point out, existing trademark doctrine fails to provide a clean answer to the question of whether one can face liability for "using" a trademark as an information-indexing tool. We differ, however, over the

in the nineteenth century, see Mark P. McKenna, The Normative Foundations of Trademark Law, 82 NOTRE DAME L. REV. 1839, 1860 (2007).

5. See generally Stacey L. Dogan, An Exclusive Right to Evoke, 44 B.C. L. REv. 291 (2003); Jessica Litman, Breakfast with Batman: The Public Interest in the Advertising Age, 108 YALE L.J. 1717 (1999).

6. Felix Cohen raised such concerns as early as the 1930s, and Ralph Brown took up the call in the middle of the last century. See, e.g., Ralph S. Brown, Jr., Advertising and the Public Interest: Legal Protection of Trade Symbols, 57 YALE L.J. 1165, 1177-80 (1948); Felix Cohen, Transcendental Nonsense and the Functional Approach, 35 Colum. L. ReV. 809, 815 (1935). Contemporary scholars, including Jessica Litman, Rochelle Dreyfuss, and others, have reinforced and expanded upon their admonitions about the dangers of overly protective trademark laws. See, e.g., Rochelle Cooper Dreyfuss, Expressive Genericity: Trademarks as Language in the Pepsi Generation, 65 Notre Dame L. Rev. 397, 405 (1990); Mark A. Lemley, The Modern Lanham Act and the Death of Common Sense, 108 YALE L.J. 1687, 1694-1713 (1999); Litman, supra note 5, at 1728-35; Glynn S. Lunney, Jr., Trademark Monopolies, 48 EMORY L.J. 367, 421-31 (1999).

7. Eric Goldman, Deregulating Relevancy in Internet Trademark Law, 54 EMORY L.J. 507, 511$28(2005)$.

8. A customer searching for "Disneyworld vacation," for example, might receive advertisements for reasonably priced hotels in the greater Orlando area. See generally Stacey L. Dogan, Trademarks and Consumer Information, in NOUVELles APPROCHES EN PROPRIÉTÉ InTEllectuelle dands un Monde TranssystémiQue [INTEllectual Property at the Edge: New APPROACHES to IP IN A TRANSSYSTEMIC WORLD] 321 (2007); Goldman, supra note 7, at 521-24 (discussing the various reasons people might use a trademark as a search term). 
reason for that failure as well as the appropriate response. Dinwoodie and Janis contend that the trademark use doctrine did not emerge until recently because trademark law does not, and should not, include any limitation on the type of uses that can subject one to infringement liability. ${ }^{9}$ But there is another, and in our view more likely, explanation for the absence of an explicit trademark use requirement historically: the vast majority of cases in the pre-Internet era involved defendants that clearly had used the mark (or something like it) as a visible device in marketing their own products. Courts rarely addressed the limits of trademark use because they rarely faced claims against parties whose use of a trademark did not fit the traditional model. On the rare occasion that they did face such claims, courts (including the Supreme Court) relied on theories of secondary liability, which suggested that they presumed a limitation on the acts that could constitute direct infringement. $^{10}$

Trademark law, then, is at something of a crossroads. Dinwoodie and Janis correctly argue that the choices that courts make at this crossroads will have a tremendous impact on both Internet-based commerce and on the overall evolution of trademark law. Like them, we fear what will happen if the courts get it wrong. But while they fear a world of informational overload and deception if trademark holders cannot control all uses of their marks, we fear the opposite: a world in which intermediaries, for fear of liability, fail to use consumer-generated trademark signals at all in designing their business models. In this world, Amazon.com would hesitate before recommending alternative, lower-cost electronics products to a consumer seeking an expensive brand. Disney could prevent local hotels from advertising cheaper rooms than can be found at the official Disney hotel to travelers using a search engine to plan their Disney World vacation. Grocery stores would risk liability for locating generic drugs or low-cost colas next to their brand-name counterparts. Critics would shy away from identifying a company using its mark. Writers of books, movies, and television shows would face potential liability for using titles or depicting products that evoke trademarks in the minds of consumers. ${ }^{11}$ And soccer fans would have to take

9. Dinwoodie \& Janis, supra note 1 , at 1604 .

10. E.g., Inwood Labs., Inc. v. Ives Labs., Inc., 456 U.S. 844, 853-54 (1982) (discussing when contributory liability may arise); Lockheed Martin Corp. v. Network Solutions, Inc., 194 F.3d 980, 983-85 (9th Cir. 1999).

11. Lest anyone think this is a parade of horribles with no basis in reality, we note that suits of this sort are already beginning and that district courts are occasionally misled into allowing them. See generally American Dairy Queen Corp. v. New Line Prods., Inc., 35 F. Supp. 2d 727 (D. Minn. 1998) (enjoining a movie about a beauty contest in a rural state from using the title "Dairy Queens"; the movie was eventually released as "Drop Dead Gorgeous"); Toho Co. v. William Morrow \& Co., 33 F. Supp. 2d 1206 (C.D. Cal. 1998) (enjoining a book about Godzilla from using the title Godzilla, despite the presence of disclaimers on both the front and back covers). Other plaintiffs have failed, but the fact that the suits were brought at all is 
off their pants. ${ }^{12}$ While big brands like Sony, Disney, and Coke might benefit, others would suffer: upstarts, low-cost competitors, sellers of complementary products, information intermediaries, and-most importantly for purposes of trademark law-consumers.

The costs of expanding the circle of trademark defendants are therefore quite substantial. The evolution of the trademark use doctrine reflects an attempt to ground trademark law in the kinds of claims it has traditionally countenanced, both by focusing its mission and by minimizing collateral damage from overly sweeping trademark claims. Despite what Dinwoodie and Janis claim, we do not view the trademark use doctrine as a panacea, a silver bullet, or a wonder theory. Indeed, as we explore in this Article, the trademark use doctrine has significant limitations that curtail its efficacy in marginal cases. Its real importance-and the place where the theory is gaining some traction-is in curtailing an utterly new form of trademark claim against parties that do not promote their own products or services under the protected mark. In this Article, we explore the theoretical and doctrinal foundations for the trademark use theory against the backdrop of the dominant economic model of trademark law.

The remainder of this Article will proceed in three parts. Part II situates the trademark use requirement within existing trademark doctrine. We contend that the trademark use requirement finds support in both statutory and case law. At the same time, Dinwoodie and Janis are correct to point out that neither judges nor scholars have yet articulated a satisfying definition of

worrisome. See, e.g., E.S.S. Entm't 2000, Inc. v. Rock Star Videos, Inc., 444 F. Supp. 2d 1012, 1048-49 (C.D. Cal. 2006) (denying a strip club's infringement claim against a video-game manufacturer that included a like-named strip club in its game); Wham-O, Inc. v. Paramount Pictures Corp., 286 F. Supp. 2d 1254, 1265 (N.D. Cal. 2003) (refusing to enjoin a depiction of a Slip-N-Slide toy in a movie); Caterpillar Inc. v. Walt Disney Co., 287 F. Supp. 2d 913, 923-24 (C.D. Ill. 2003) (refusing to enjoin a depiction of bulldozers that resembled the plaintiff's in an animated film); Compagnie Generale des Etablisessements Michelin \& Michelin Cie. v. Nat'1 Auto., Aerospace, Transp., and Gen. Workers Union of Canada (CAW-Can.), [1997] 2 F.C. 302 (Can.), available at http://reports.fja..gc.ca/en/1996/1997fc19917.html/1997fc19917.html (refusing to enjoin a union from using the logo of the company it was trying to unionize as part of a leafleting campaign).

12. This last one requires some explanation. FIFA, the organizer of the soccer World Cup, forced more than one thousand male fans of the Dutch soccer team to remove their pants before entering the stadium to watch a 2006 game against the Ivory Coast. The fans were wearing pants in the colors of the Dutch soccer team that had been provided by a beer company and featured the beer company logo. FIFA argued that the fact that the clothes were in team colors meant that others would wrongly think that the beer company was an official sponsor of the World Cup. Rather than merely suing the beer company, however, FIFA took the position that the individuals wearing the offending pants were themselves violating the law and required them to remove the pants to enter the stadium. More than one thousand fans did so and cheered their team in their underwear. See Heather Smith, Goal Tending, IP LAW \& Bus., Aug. 2006, at 28. 
trademark use. ${ }^{13}$ Instead of a separate element in a trademark holder's prima facie case, the doctrine has emerged as a series of defenses that protect certain types of non-trademark uses against claims by trademark holders. We propose a framework for understanding the trademark use doctrine. Because of definitional problems, we find it undesirable for the doctrine to play a role in all cases. Sometimes it is impossible to determine whether a defendant is using a mark to indicate its products' source or sponsorship without resorting to the type of consumer-perception analysis that sits at the core of the likelihood-of-confusion test. ${ }^{14}$ Its limited value in close cases, however, does not mean that the trademark use doctrine has no value in non-marginal ones. Rather than a "panacea for every ill afflicting trademark law," ${ }^{15}$ the trademark use doctrine, properly applied, serves as a limited tool for identifying classes of behavior that cannot constitute infringement.

Part III addresses trademark use from a normative perspective. Without a trademark use requirement, we contend, trademark holders could severely limit a whole host of legitimate but unauthorized uses of their marks, particularly (but not exclusively) in the online context. The likelihood-of-confusion standard, moreover, has warts of its own that make sole reliance on it both problematic and costly. Part III concludes that a trademark use requirement is critical to maintaining the historical balance of trademark law, which aims to prevent specific instances of harmful confusion without casting the net so wide as to inhibit truthful, informationenhancing speech.

Finally, in Part IV, we address particular concerns that Dinwoodie, Janis, and others raise about the trademark use doctrine and its potential impact on both legal doctrine and the marketplace. Unlike them, we do not see this as a choice between abstract rules and contextualism or between form and function in achieving largely similar goals. Indeed, abolishing the distinction between direct and indirect infringement would itself reflect a shift toward a noncontextualist approach. It is not realistic to suggest, as Dinwoodie and Janis implicitly do, that we should abolish the existing trademark use doctrine and then re-enact essentially all of its applications as special statutory rules. If we broach this limit, trademark law will inevitably expand, and we will all be the poorer for it.

13. Dinwoodie \& Janis, supra note 1 , at 1647-53.

14. We are indebted to Mark McKenna for persuading us of this point.

15. Dinwoodie \& Janis, supra note 1 , at 1621. 


\section{The CASE FOR TRADEMARK USE}

\section{A. HISTORY AND DOCTRINE}

Dinwoodie and Janis base much of their critique on the descriptive contention that trademark law has never required trademark use as a basis for liability. The trademark use doctrine, they contend, has appeared out of thin air, imposing a new and unjustifiable limitation on trademark owners' rights. ${ }^{16}$ From its earliest days, however, United States trademark law has defined infringement in a way that presumes a trademark use requirement. Both the Lanham Act and the likelihood-of-confusion test focus on parties that create confusion in the promotion of their own products. Courts, including the Supreme Court, have distinguished between direct infringers-parties that sell products under the infringing mark-and those with a more indirect role in the infringement. ${ }^{17}$ The modern suits against intermediaries for direct infringement reflect an attempt to conflate these two doctrines, and the trademark use doctrine evolved as a reaction to that expansionary impulse. The recent trademark use decisions, therefore, are simply articulating and refining a longstanding principle of trademark law that finds support in both the Lanham Act and relevant case law, a principle that was, until recently, so widely accepted that trademark owners never sought to challenge it. ${ }^{18}$

We begin with the statute. The Lanham Act defines infringement as a "use in commerce" of a mark "in connection with the sale, offering for sale, distribution, or advertising of any goods or services on or in connection with which such use is likely to cause confusion, or to cause mistake, or to deceive." ${ }^{\prime 19}$ The statute thus places two qualifications on the type of use that can constitute infringement: it must be a "use in commerce," and it must be "in connection with" the sale, offering, or advertising of goods and services.

We have suggested elsewhere that the "use in commerce" requirement plays primarily a jurisdictional role in trademark cases by limiting trademark claims to those involving interstate commerce. ${ }^{20}$ As others have pointed out, however, the Lanham Act contains a definition of "use in commerce" that is

16. Id. at 1608-20. Tom McCarthy makes a similar argument. 4 J. THOMAS MCCARTHY, MCCARTHY ON TRADEMARKS AND UNFAIR COMPETITION $§ 23: 11.50$ (4th ed. 2007).

17. See, e.g., Banff Ltd. v. Limited, Inc., 869 F. Supp. 1103, 1111 (S.D.N.Y. 1994) (" $[\mathrm{L}]$ iability for non-direct infringers under trademark law is narrower than liability under the copyright laws.").

18. See Margreth Barrett, Internet Trademark Suits and the Demise of "Trademark Use", 39 U.C. DAVIS L. REV. 371, 376-87 (2006) (detailing the history of the trademark use requirement).

19. 15 U.S.C. $\$ 1114(1)$ (a) (2000) (defining infringement of registered marks); see also id. $\$ 1125$ (a) (providing a parallel cause of action for unregistered marks).

20. Stacey L. Dogan \& Mark A. Lemley, Trademarks and Consumer Search Costs on the Internet, 41 Hous. L. REV. 777, 806 (2004). 
far more limited in scope. ${ }^{21}$ The statute defines "use in commerce" as "the bona fide use of a mark in the ordinary course of trade, and not made merely to reserve a right in a mark."22 Congress drafted the "use in commerce" definition narrowly to include only uses likely to establish a connection between a mark and a product or service in the minds of consumers. For goods, "use in commerce" requires that the mark be placed on the products, their containers, or labels or documents associated with the sale; for services, the definition allows use in advertising or sales materials. ${ }^{23}$

On its face, the "use in commerce" definition appears to limit infringement of a product mark to visible uses of the mark on or near the defendant's product itself. ${ }^{24}$ The infringement provision, however, clearly encompasses advertising uses as well. ${ }^{25}$ Faced with the tension between these two provisions, courts have two choices. They can ignore the statutory definition of "use in commerce" in the infringement context, or they can attempt to reconcile it with the infringement provision. General rules of statutory construction argue in favor of reconciling the two if possible. ${ }^{26} \mathrm{~A}$ reasonable reading of the "use in commerce" definition in the infringement context would limit infringement to the general sorts of uses listed in the definition-i.e., uses that employ the trademark as a brand.

21. See, e.g., Barrett, supra note 18 , at $382-86$.

22. 15 U.S.C. $\$ 1127$.

23. Id. $\S 1127$. The full definition provides:

The term "use in commerce" means the bona fide use of a mark in the ordinary course of trade, and not made merely to reserve a right in a mark. For purposes of this chapter, a mark shall be deemed to be in use in commerce- (1) on goods when- (A) it is placed in any manner on the goods or their containers or the displays associated therewith or on the tags or labels affixed thereto, or if the nature of the goods makes such placement impracticable, then on documents associated with the goods or their sale, and (B) the goods are sold or transported in commerce, and (2) on services when it is used or displayed in the sale or advertising of services and the services are rendered in commerce, or the services are rendered in more than one State or in the United States and a foreign country and the person rendering the services is engaged in commerce in connection with the services.

Id. $\$ 1127$.

24. For service marks, the "use in commerce" definition expressly includes use in advertising. Id. § 1127 .

25. Id. § 1114, 1125(a). See generally Barrett, supra note 18, at 384 (noting the inconsistency in statutory language).

26. Florida Dep't of Banking \& Fin. v. Board of Governors of Fed'l Reserve Sys., 800 F.2d 1534, 1536 (11th Cir. 1986) ("It is an elemental precept of statutory construction that the definition of a term in the definitional section of a statute controls the construction of that term wherever it appears throughout the statute."); see also Crooks v. Harrelson, 282 U.S. 55, 60 (1930) (noting that courts should "override the literal terms of a statute only under rare and exceptional circumstances," in which "the absurdity [is] so gross as to shock the general moral or common sense"). 
In any event, when read together, the "use in commerce" and "in connection with" requirements have been widely understood to impose infringement liability only on those who created confusion in the process of selling, marketing, or advertising their own products. ${ }^{27}$ The case law, both before and after passage of the Lanham Act, bears out this interpretation. ${ }^{28}$

27. Many courts adopting the trademark use doctrine have relied upon the "in connection with" language in the Lanham Act. See, e.g., Bosley Med. Inst., Inc. v. Kremer, 403 F.3d 672, 67980 (9th Cir. 2005) (finding the appropriate inquiry in evaluating the "in connection with" requirement, as "whether [defendant] offers competing services to the public"); DaimlerChrysler AG v. Bloom, 315 F.3d 932, 939 (8th Cir. 2003) (" $[T]$ he licensing of a toll-free telephone number, without more, is not a 'use' within the meaning of the Lanham Act ...."); Holiday Inns, Inc. v. 800 Reservation, Inc., 86 F.3d 619, 623-26 (6th Cir. 1996) (holding that the use of a telephone number that translated into 1-800-H0LIDAY-with a zero in place of the "O"-was not trademark "use" within the Lanham Act because the defendant had not advertised its services under the offending alphabetical translation). Others have relied on the "use in commerce" language. See, e.g., 1-800 Contacts, Inc. v. WhenU.com, Inc., 414 F.3d 400, 407-11 (2d Cir. 2005) (relying on the "use in commerce" requirement to find no direct infringement by a party selling pop-up advertisements); Karl Storz Endoscopy-Am., Inc. v. Surgical Techs., Inc., 285 F.3d 848, 855 (9th Cir. 2002) (“'[U]se in commerce' appears to contemplate a trading upon the goodwill of or association with the trademark holder."); Site Pro-1, Inc. v. Better Metal, LLC, No. CV-06-6508, 2007 WL 1385730, at *4 (E.D.N.Y. May 9, 2007); Best Western Int'l, Inc. v. Doe, No. CV-06-1537-PHX-DGC, 2006 WL 2091695, at *5 (D. Ariz. July 25, 2006); $c f$. Hamzik v. Zale Corp., No. 3:06-cv-1300, 2007 WL 1174863, at *3 (N.D.N.Y. April 19, 2007) (finding potential trademark use by a keyword advertiser that displayed plaintiff's trademark in the text of its ad). Still others have held that the trademark use doctrine bars claims without specific reference to statutory language. See, e.g., Universal Comm. Sys., Inc. v. Lycos, Inc., 478 F.3d 413, 424 (1st Cir. 2007) (rejecting a state dilution claim because "Lycos might profit by encouraging others to talk about UCS under the UCSY name, but neither that speech nor Lycos's providing a forum for that speech is the type of use that is subject to trademark liability"); Nautilus Group, Inc. v. Icon Health \& Fitness, Inc., No. CO2-242ORSM, 2006 WL 3761367, at *5 (W.D. Wash. Dec. 21, 2006) (holding that an advertiser's use of a keyword to generate a sponsored link to run a comparative advertisement was not a trademark use for dilution purposes); Merck \& Co., Inc. v. Mediplan Health Consulting, Inc., 431 F. Supp. 2d 425, 428 (S.D.N.Y. 2006); Rescuecom Corp. v. Google, Inc., 456 F. Supp. 2d 393, 398-403 (N.D.N.Y. 2006) (finding that sale of keyword-based advertising does not constitute "trademark use"); Lucasfilm Ltd. v. High Frontier, 622 F. Supp. 931, 934-35 (D.D.C. 1985).

While one could argue that manufacturers that suggest to retailers that the retailers use a mark in infringing ways have themselves "used" the mark "in connection with" the product sales process, thereby satisfying the broadest reading of this provision, such a reading would compel a similarly broad interpretation of the language for eligibility purposes, so that advertising and internal uses would suffice for protection. Courts have consistently rejected such a broad interpretation in the eligibility context, Zazu Designs v. L'Oreal, S.A., 979 F.2d 499, 505 (7th Cir. 1992); Blue Bell, Inc. v. Farah Mfg. Co., 508 F.2d 1260, 1265-68 (5th Cir. 1975), and we think they should similarly reject that broad interpretation in the infringement context. Such behavior by manufacturers has always been considered under the stricter standards of contributory infringement, and we think that is the proper approach. See, e.g., William R. Warner \& Co. v. Eli Lilly \& Co., 265 U.S. 526, 530-31 (1924); Hostetter Co. v. Brueggeman-Reinert Distilling Co., 46 F. 188, 188 (E.D. Mo. 1891) (finding a manufacturer liable for "counsel[ing] and advis[ing]" its retailers to commit fraudulent product substitution).

28. For a discussion of the pre-Lanham Act case law, which clearly required use as a mark affixed to the defendant's goods, see Barrett, supra note 18, at 379-81. 
For one thing, the likelihood-of-confusion standard-which Dinwoodie and Janis rightly identify as the core focus of trademark law-takes for granted that the defendant is using the mark to promote its own sales. Courts describing the test speak in terms of the likelihood of confusion between a plaintiff's and a defendant's products or services. ${ }^{29}$ Most of the likelihood-of-confusion factors, moreover, call for an examination of the nature of the particular defendant's use of the mark in connection with its products. ${ }^{30}$ Courts consider, for example, the proximity between a plaintiff's and a defendant's products, the relative marketing channels used by each, the degree of overlap in sales outlets and customers, and the sophistication and other characteristics of the parties' respective customers. ${ }^{31}$ Each of these factors involves a contextual inquiry into which products or services the parties are marketing under the mark and in what commercial context—all

29. In AMF, Inc. v. Sleekcraft Boats, for example, the court noted:

When the goods produced by the alleged infringer compete for sales with those of the trademark owner, infringement usually will be found if the marks are sufficiently similar that confusion can be expected. When the goods are related, but not competitive, several other factors are added to the calculus. If the goods are totally unrelated, there can be no infringement because confusion is unlikely.

AMF, Inc. v. Sleekcraft Boats, 599 F.2d 341, 348 (9th Cir. 1979); see also Daddy's Junky Music Stores, Inc. v. Big Daddy's Family Music Ctr., 109 F.3d 275, 280 (6th Cir. 1997) (stating that infringement turns on "whether the defendant's use of the disputed mark is likely to cause confusion among consumers regarding the origin of the goods offered by the parties"); Blue Bell Bio-Medical v. Cin-Bad, Inc., 864 F.2d 1253, 1256 (5th Cir. 1989) ("Infringement occurs only when there is a likelihood of confusion between the products of the plaintiff and the defendant." (emphasis added)); RESTATEMENT (THIRD) OF UNFAIR COMPETITION § $21 \mathrm{cmt}$. a (1995) ("The test for infringement is whether the actor's use of a designation as a trademark, trade name, collective mark, or certification mark creates a likelihood of confusion . ..."); $c f$. Hubbard Feeds, Inc. v. Animal Feed Supply, Inc., 182 F.3d 598, 602 (8th Cir. 1999) ("The ultimate inquiry always is whether, considering all the circumstances, a likelihood exists that consumers will be confused about the source of the allegedly infringing product.").

30. While the specific factors vary among jurisdictions, the essential inquiry is quite similar from one circuit to the next. See, e.g., Polaroid Corp. v. Polarad Elecs. Corp., 287 F.2d 492, 495 (2d Cir. 1961). In that case, the Second Circuit stated:

Where the products are different, the prior owner's chance of success is a function of many variables: the strength of his mark, the degree of similarity between the two marks, the proximity of the products, the likelihood that the prior owner will bridge the gap, actual confusion, and the reciprocal of defendant's good faith in adopting its own mark, the quality of defendant's product, and the sophistication of the buyers.

Id.; AMF, 599 F.2d at 348-49 (listing Ninth Circuit factors); Beer Nuts, Inc. v. Clover Club Foods Co., 711 F.2d 934, 940 (10th Cir. 1983). For a catalogue of the multi-factor tests in various circuits, see generally Barton Beebe, An Empirical Study of the Multifactor Tests for Trademark Infringement, 94 CAL. L. REV. 1581 (2006).

31. Falcon Rice Mill, Inc. v. Cmty. Rice Mill, Inc., 725 F.2d 336, 346 (5th Cir. 1984) (stating that the likelihood-of-confusion test considers the two parties' "products, outlets, purchasers, and marketing methods"). 
inquiries that become meaningless unless the defendant is actually using the mark to promote its own product. ${ }^{32}$

Perhaps the most compelling evidence of the trademark use requirement is the series of cases beginning in the late 1800s that defined the circumstances in which an individual can face liability for another's direct infringement. ${ }^{33}$ The concept of indirect trademark infringement has a long pedigree. Like many trademark doctrines, it finds no express support in the trademark statute, but the courts borrowed it from tort law to reflect the impulse that "[o]ne who induces another to commit a fraud and furnishes the means of consummating it is equally guilty and liable for the injury." ${ }^{34}$ The Supreme Court first recognized the doctrine in William R. Warner $\mathcal{E}$ Co. v. Eli Lilly $\mathcal{F}^{2}$ Co., ${ }^{35}$ a case involving dueling manufacturers of chocolatequinine beverages. Both manufacturers sold the liquid in bottle form to "druggists," who then sold it to the public "in its naked form out of the bottle." ${ }^{36}$ The plaintiff sold a popular and high-quality version of the drink. The defendant sold a cheaper version, and the evidence showed that its salesmen had suggested to druggists "that, without danger of detection, prescriptions for [the original] could be filled by substituting" the

32. Examples abound of cases that end up discarding the likelihood-of-confusion factors wholesale because they are seeking to apply the doctrine in the absence of a trademark use. Perhaps most notable is Brookfield Commc'ns v. W. Coast Entm't Corp., 174 F.3d 1036, 1058-60 (9th Cir. 1999) (throwing out the majority of confusion factors as irrelevant in the Internet context).

The Tenth Circuit recently identified this as a reason for the development of contributory liability. See Procter \& Gamble Co. v. Haugen, 317 F.3d 1121, 1128 (10th Cir. 2003) ("Because the infringement test initially adopted under the Lanham Act is not well suited for targeting . . . secondary liability, an additional theory of liability was warranted.").

33. See, e.g., William R. Warner \& Co. v. Eli Lilly \& Co., 265 U.S. 526, 530-31 (1924); Coca Cola Co. v. Gay-Ola Co., 200 F. 720, 723 (6th Cir. 1912); Hostetter Co. v. Brueggeman-Reinert Distilling Co., 46 F. 188, 189 (C.C.E.D. Mo. 1891); see also Rathbone, Sard \& Co. v. Champion Steel Range Co., 189 F. 26, 33 (6th Cir. 1911) ("[D] efendant is not responsible for the fact that tricky retailers represent its manufacture as that of complainant."). The Supreme Court most recently addressed indirect trademark liability in Inwood Labs. v. Ives Labs., 456 U.S. 844 (1982):

Even if a manufacturer does not directly control others in the chain of distribution, it can be held responsible for their infringing activities under certain circumstances. Thus, if a manufacturer or distributor intentionally induces another to infringe a trademark, or if it continues to supply its product to one whom it knows or has reason to know is engaging in trademark infringement, the manufacturer or distributor is contributorily responsible for any harm done as a result of the deceit.

Id. at $853-54$.

34. William R. Warner $\mathcal{E}$ Co., 265 U.S. at 530-31.

35. Id. See generally John T. Cross, Contributory Infringement and Related Theories of Secondary Liability for Trademark Infringement, 80 IOWA L. REV. 101 (1994) (exploring the history and foundations of the contributory infringement doctrine).

36. William R. Warner Eo Co., 265 U.S. at 530. 
defendant's product. ${ }^{37}$ Despite the fact that the manufacturer had not directly caused any confusion or deception-the druggists, after all, knew exactly what they were buying-the Court found liability appropriate. "The wrong," held the Court, "was in designedly enabling the dealers to palm off the preparation as that of the respondent." 38

The defendant in this case clearly "used" the trademark in its discussions with druggists in some broad sense, and indeed its use of the mark was a causal link in the consumer confusion that ultimately ensued. Yet courts have always treated claims against parties like this one as claims of contributory or indirect liability, not direct infringement. Courts have consistently distinguished between parties that facilitate infringement and direct infringers that actually hold their products or services out to the public under the offending mark. ${ }^{39}$

Historically, courts also invoked contributory, rather than direct, infringement standards in situations in which the defendant actually affixed a mark to a product-surely a use in the broadest sense-but did not itself sell the product to the public under the mark. In Andrew Jergens Co. v. Bonded Products Corp. ${ }^{40}$ for example, a soap manufacturer filled orders for soap whose name was confusingly similar to the defendant's trademark. The manufacturer defended on the basis that it had not created consumer confusion because it did not sell the soap to the public. ${ }^{41}$ While the court agreed that the manufacturer had not directly infringed, it found the manufacturer liable on a theory of contributory infringement. ${ }^{42}$ Despite the fact that the defendant had actually created the offending labels and affixed them to the product, its liability was derivative of that of the defendant who sold the product to the public under the mark. Congress has since revised the trademark law to prohibit the specific behavior at issue in Jergens, ${ }^{43}$ but

37. Id.

38. Id.

39. Cf. Hard Rock Café Licensing Corp. v. Concession Servs., Inc., 955 F.2d 1143, 1148 (7th Cir. 1992) (noting that "it is not clear how the [contributory infringement] doctrine applies to people who do not actually manufacture or distribute the good that is ultimately palmed off as made by someone else").

40. Andrew Jergens Co. v. Bonded Prods. Corp., 21 F.2d 419, 422 (2d Cir. 1927).

41. Id. at 424 .

42. $I d$.

43. See 15 U.S.C. $\$ 1114(1)$ (b) (2000). Section 1114(1)(5) provides for liability against any party that shall

reproduce, counterfeit, copy, or colorably imitate a registered mark and apply such reproduction, counterfeit, copy, or colorable imitation to labels, signs, prints, packages, wrappers, receptacles or advertisements intended to be used in commerce upon or in connection with the sale, offering for sale, distribution, or advertising of goods or services on or in connection with which such use is likely to cause confusion, or to cause mistake, or to deceive. 
the fact that it felt the need to address the labeling situation-and did so surgically-suggests that in other cases involving defendants that do not offer goods to the public under the mark, the contributory infringement standard should continue to apply. ${ }^{44}$ Indeed, to apply direct infringement in these cases would render the doctrine of contributory infringement a nullity. ${ }^{45}$

A closer look at infringement doctrine throughout history, then, establishes that the trademark use requirement is more than a mirage. The statute suggests-and the likelihood-of-confusion inquiry confirms-a definition of infringement that presumes the defendant is promoting its own goods and services under the mark. Courts have consistently distinguished between these direct infringers and those whose liability, if it exists, turns on their knowing facilitation or inducement of the direct infringer's acts. ${ }^{46}$ The distinction makes good sense. As Dinwoodie and Janis argue, context is critical in trademark law. ${ }^{47}$ Only by considering the overall relationship between two parties' products, marks, and sales practices can courts evaluate whether a defendant's use of a trademark is likely to confuse consumers about the source or sponsorship of its products. And only if that party is infringing do we reach the question of whether some other party should face responsibility for that infringement. Judging a search engine's liability for allowing advertisers to place keyword-based ads, then, makes no sense without reference to a particular advertisement placed by a particular party and without evaluating the search engine's relationship to that party and that ad.

Id. $\S 1114(1)(\mathrm{b})$.

44. The language of $\S 1114$, moreover, limits liability to injunctive relief "unless the acts have been committed with knowledge that such imitation is intended to be used to cause confusion, or to cause mistake, or to deceive." Id. § 1114 .

45. This was a problem in Marvel Enterprises, Inc. v. NCSoft Corp., 74 U.S.P.Q.2d 1303, 1305 (C.D. Cal. 2005), where the defendant sold a computer game called "City of Heroes" that allowed players to create their own superhero characters. When some players created characters that looked like Marvel Comics heroes, Marvel sued for trademark infringement. Id. The court rejected the claim of contributory trademark infringement, finding that the individual players were not engaged in trademark use and that, therefore, there was no infringement to which the defendant could contribute. Id. at 1308-09. Inexplicably, however, the court allowed Marvel to proceed on a claim that selling the game was an act of direct infringement. Id. at 1308. Marvel demonstrates the problems with ignoring trademark use in analyzing claims of direct infringement in circumstances that are better analyzed under contributory infringement standards.

46. See Cross, supra note 35, at 104 (presuming the "in connection with" requirement to apply only to parties that "themselves sell the underlying product"); $c f$. MCCARTHY, supra note 16 , at $\$ 25: 17$ ("Liability for trademark infringement and unfair competition may be extended beyond those who actually sell goods with the infringing mark, to include all those contributory infringers who knowingly cooperate in illegal and tortious activity.").

47. Dinwoodie \& Janis, supra note 1 , at 1654 . 
It is equally clear that courts today widely recognize the trademark use doctrine. ${ }^{48}$ While it is true that express references to trademark use as a threshold requirement for an infringement suit are relatively new, that is a function of the fact that, traditionally, trademark owners have not claimed that intermediaries or even competitors that did not use the mark to identify the source or affiliation of their goods or services were engaged in direct infringement. In those rare older cases where trademark owners did make such claims, courts were express in rejecting them because the defendant did not use the term "as a designation of source." ${ }^{49}$ As that has started to change-as trademark owners have asserted claims against search engines, software providers who deliver content based on consumer choices, and even those that locate a trademark in a URL ${ }^{50}$ - courts have had to make explicit limitations of trademark liability that have long been implicit.

\section{B. TRADEMARK USE IN CONTEXT}

While we have no doubt about the existence of a trademark use doctrine, Dinwoodie and Janis raise legitimate concerns about the potential pitfalls of applying the doctrine at the boundaries. Strictly speaking, trademark infringement should require not only that a defendant be using the mark to promote its own products or services but also that it be using it "as a mark"-i.e., to indicate the source or sponsorship of those products or services. Absent a suggestion of source or sponsorship, after all, it is hard to argue that the defendant is creating confusion as to either. ${ }^{51}$ Nonetheless, we recognize that applying the use-as-a-mark requirement in every case would be counterproductive. In some cases, evaluating whether a defendant is using a mark as a trademark on its products requires inquiry into consumer

48. See, e.g., Bosley Med. Inst., Inc. v. Kremer, 403 F.3d 672, 679-80 (9th Cir. 2005); DaimlerChrysler AG v. Bloom, 315 F.3d 932, 939 (8th Cir. 2003); Holiday Inns, Inc. v. 800 Reservation, Inc., 86 F.3d 619, 623-26 (6th Cir. 1996); 1-800 Contacts, Inc. v. WhenU.com, Inc., 414 F.3d 400, 407-11 (2d Cir. 2005); Karl Storz Endoscopy-Am., Inc. v. Surgical Techs., Inc., 285 F.3d 848, 855 (9th Cir. 2002); Best Western Int'l, Inc. v. Doe, No. CV-06-1537-PHX-DGC, 2006 WL 2091695, at *5 (D. Ariz. July 25, 2006); Nautilus Group, Inc. v. Icon Health \& Fitness, Inc., No. CO2-242ORSM, 2006 WL 3761367, at *5 (W.D. Wash. Dec. 21, 2006); Merck \& Co., Inc. v. Mediplan Health Consulting, Inc., 431 F. Supp. 2d 425, 428 (S.D.N.Y. 2006); Rescuecom Corp. v. Google, Inc., 456 F. Supp. 2d 393, 398-403 (N.D.N.Y. 2006); Lucasfilm Ltd. v. High Frontier, 622 F. Supp. 931, 934-35 (D.D.C. 1985).

49. Avery \& Sons v. Meikle \& Co., 4 Ky. L. Rptr. 759, 763-64 (1883).

50. See, e.g., Interactive Products v. a2z Mobile Solutions, 326 F.3d 687, 698 (6th Cir. 2003); Patmont Motor Werks v. Gateway Marine, Inc., No. C96-2703, 1997 WL 811770, at *4 n.6 (N.D. Cal. Dec. 18, 1997).

51. See 15 U.S.C. $\$ \S 1114,1125$ (2000) (prohibiting use "likely to cause confusion"); Malletier v. Burlington Coat Factory Warehouse Corp., 426 F.3d 532, 538 (2d Cir. 2005) (" $[\mathrm{T}]$ he Lanham Act requires a court to analyze the similarity of the products in light of the way in which the marks are actually displayed in their purchasing context."). 
perceptions about the use-an inquiry that turns on many of the same factors as the likelihood-of-confusion analysis. ${ }^{52}$

The trademark use doctrine's limited utility in borderline cases, however, is not reason enough to abandon it. Rather, we think the doctrine can develop inductively, building from clear cases in which the defendant does not use the plaintiff's mark to identify or brand its goods or services. How far the doctrine extends may be the subject of litigation as new classes of cases arise, but that is no more reason to abandon the trademark use doctrine than it would be to give up on any other common-law standard.

The trademark use requirement has always stood in the background as both the courts and Congress defined the reach and limits of trademark holders' rights. As discussed above, the trademark use notion lies at the core of the affirmative standard for likelihood of confusion. ${ }^{53}$ But as a doctrine, its primary value is to insulate certain categories of behavior from trademark liability. These categories tend to share two characteristics: first, the defendant has used the trademark in a non-source-identifying (and nonsponsorship-identifying) way; and second, the error costs from a pro-plaintiff verdict are high. ${ }^{54}$ The descriptive fair use doctrine, ${ }^{55}$ the exemption for comparative advertising, ${ }^{56}$ the nominative fair use doctrine,${ }^{57}$ and the safe

52. The trade dress cases are a good example. Whether consumers view similarities in trade dress as aesthetic or source identifying will determine both the question of trademark use and that of infringement. Merchandising cases, too, involve difficult questions about whether consumers believe that trademark holders have sponsored or licensed merchandise bearing their marks. While we doubt that consumers traditionally had such an assumption, they may have developed it over time, at least in the professional sports context. We have critiqued the merchandising right elsewhere, not on the basis of trademark use, but because courts in the early merchandising cases failed to inquire into likelihood of confusion, as the Lanham Act requires. See generally Stacey L. Dogan \& Mark A. Lemley, The Merchandising Right: Fragile Theory or Fait Accompli ?, 54 EMORY L.J. 461 (2005).

53. 15 U.S.C. $\$ \S 1114(1), 1125(a)$ (defining infringement to require confusion as to source, sponsorship, or affiliation).

54. In other words, if a jury were to get it wrong and conclude that the defendant's use of the mark was likely to confuse the public as to source or sponsorship, the public would suffer through the loss of some valuable speech or marketplace competition.

55. 15 U.S.C. $\$ 1115$ (b) (4); see Sunmark, Inc. v. Ocean Spray Cranberries, Inc., 64 F.3d 1055, 1059 (7th Cir. 1995) (describing the fair use defense); Zatarains, Inc. v. Oak Grove Smokehouse, Inc., 698 F.2d 786, 791, 796 (5th Cir. 1983) (same).

56. Saxlehner v. Wagner, 216 U.S. 375, 380 (1910) (allowing imitator to use trademark "to tell the public what they are doing and to get whatever share they can in the popularity of the [trademarked product] by advertising that they are trying to make the same article and think that they succeed"); Smith v. Chanel, Inc., 402 F.2d 562, 566 (9th Cir. 1968) ("The courts . . have generally confined legal protection to the trademark's source identification function for reasons grounded in the public policy favoring a free, competitive economy."); accord Calvin Klein Cosmetics Corp. v. Lenox Labs., Inc., 815 F.2d 500, 503-04 (8th Cir. 1987) (upholding competitor's use of the Calvin Klein mark OBSESSION if used in a nondeceptive, comparative manner); G.D. Searle \& Co. v. Hudson Pharm. Corp., 715 F.2d 837, 842 \& n.12 (3d Cir. 1983) (holding that a generic could advertise its product as "[e]quivalent to" plaintiff's if 
harbor for news reporting and commentary ${ }^{58}$ are all examples of nontrademark uses that are specifically exempted from trademark law either by the statute or by the courts, both because the defendant has used the mark in a legitimate and non-source-identifying way and because of the excessive social costs if a jury were to find source or sponsorship confusion likely. ${ }^{59}$

The courts' recent invocation of trademark use as a limitation on infringement claims against intermediaries shares these characteristics. Substantively, the challenged behavior does not involve use of the mark as an indicator of source or sponsorship of the defendant's products and therefore does not meet the definition of direct infringement. ${ }^{60}$ From an error-costs perspective, the cost of imposing liability against intermediaries is substantial, for reasons we explore more fully below. ${ }^{61}$ Rather than crafting an entirely new jurisprudence, then, modern courts are simply using the

accompanied by a disclaimer); Upjohn Co. v. Am. Home Prods. Corp., 598 F. Supp. 550, 561 (S.D.N.Y. 1984) (permitting the maker of Advil to advertise Advil's equivalent strength to Motrin by using the Motrin mark).

57. In New Kids on the Block v. News America Publishing, Inc., the court stated:

Such nominative use of a mark-where the only word reasonably available to describe a particular thing is pressed into service-lies outside the strictures of trademark law: Because it does not implicate the source-identification function that is the purpose of trademark, it does not constitute unfair competition; such use is fair because it does not imply sponsorship or endorsement by the trademark holder.

New Kids on the Block v. News Am. Publ'g, Inc., 971 F.2d 302, 308 (9th Cir. 1992). See generally Century 21 Real Estate Corp. v. Lendingtree, Inc., 425 F.3d 211 (3d Cir. 2005); Mattel, Inc. v. Walking Mountain Prods., 353 F.3d 792 (9th Cir. 2003); Mattel, Inc. v. MCA Records, Inc., 296 F.3d 894 (9th Cir. 2002).

58. This safe harbor is explicit in the dilution statute. See 15 U.S.C. $§ 1125$ (c)(3). But courts have protected speech about trademarks in the consumer-confusion context as well. See, e.g., Mattel, 296 F.3d at 900-02 (denying infringement claim based on the use of Barbie mark in a song title); Hormel Foods Corp. v. Jim Henson Prods., Inc., 73 F.3d 497, 502-05 (2d Cir. 1996) (finding no confusion based on parodic use of the SPAM mark); Rogers v. Grimaldi, 875 F.2d 994, 999 (2d Cir. 1989) ("[I]n general the [Lanham] Act should be construed to apply to artistic works only where the public interest in avoiding consumer confusion outweighs the public interest in free expression."); MasterCard Int'l Inc. v. Nader 2000 Primary Comm., Inc., No. 00-CIV.6068 (GBD), 2004 WL 434404, at *16 (S.D.N.Y. Mar. 8, 2004) (allowing for a politician's humorous use of commercial trademarks in political advertisements).

59. In some of these categories-particularly descriptive fair use-the Supreme Court has made clear that the defense applies even if confusion is likely. See KP Permanent Make-Up, Inc. v. Lasting Impression I, Inc., 543 U.S. 111, 121-22 (2004) ("Since the burden of proving likelihood of confusion rests with the plaintiff, and the fair use defendant has no free-standing need to show confusion unlikely, it follows ... that some possibility of consumer confusion must be compatible with fair use, and so it is.").

60. Indeed, these third-party cases fall farther from the line separating trademark use and non-use than do some of the established defenses such as descriptive fair use.

61. See infra Part III. 
trademark use requirement to identify a category of defendants that has never been-and should not now be-subject to direct infringement claims.

We think the trademark use doctrine is similarly helpful in defeating a new class of trademark claims based on juxtaposition. At the moment, those claims show up primarily in the Internet context as suits against advertisers that purchase ad space that is in proximity to certain search terms or that "pops up" on users' computers when they visit certain websites. ${ }^{62}$ But it is easy to imagine claims against the makers of generic products that purchase shelf space in a grocery or drug store next to a brand-name product, or even gas stations, burger chains, or retail outlets that intentionally locate stores or billboards next door to a competitor. The advertiser or product vendor is "using" a competitor's trademark in deciding where to place its goods, but not in a way that trademark law should care about. And here, too, the social costs of imposing liability would be substantial.

When viewed from this perspective, the trademark use doctrine does not make the statutory fair use provision in 15 U.S.C. $\S 1115(\mathrm{~b})(4)^{63}$ superfluous, as Dinwoodie and Janis contend. ${ }^{64}$ Descriptive fair use is simply one category of non-trademark use that falls explicitly beyond the purview of trademark infringement law. The fact that Congress has codified explicit exclusions for some of these categories does not foreclose courts from recognizing others, particularly those that have long been implicit in trademark law. Indeed, most of the exclusions and defenses in the Lanham Act-including descriptive fair use-began as common-law doctrines. ${ }^{65}$ And

62. See, e.g., Google, Inc. v. Am. Blind \& Wallpaper, No. C-03-5340JF (RS), 2007 WL 1159950 , at *6 (N.D. Cal. Apr. 18, 2007) (holding that a search engine's sale of keyword-based advertising can constitute trademark use under the Lanham Act); 800-JR Cigar, Inc. v. GoTo.com, Inc., 437 F. Supp. 2d 273, 282-93 (D.N.J. 2006) (allowing trademark claims against a pay-for-priority search engine based on its "sale" of keywords in exchange for prominent placement in search results); Merck \& Co., Inc. v. Mediplan Health Consulting, Inc., 431 F. Supp. 2d 425, 426-28 (S.D.N.Y. 2006) (rejecting a trademark claim based on keyword-based advertising because defendant did not make trademark use); Rescuecom Corp. v. Google, Inc., 456 F. Supp. 2d 393, 397-404 (N.D.N.Y. 2006) (same); Edina Realty, Inc. v. TheMLSonline.com, No. Civ. 04-4371JRTFLN, 2006 WL 737064, at*1-2 (D. Minn. Mar. 20, 2006) (allowing a trademark claim based on keyword-based advertising); Buying for the Home, LLC v. Humble Abode, LLC, 459 F. Supp. 2d 310, 321-24 (D.N.J. 2006) (same); Int'l Profit Assocs., Inc. v. Paisola, 461 F. Supp. 2d 672, 676-80 (N.D. Ill. 2006) (enjoining keyword advertising by a gripe site); cf. 1-800 Contacts, Inc. v. WhenU.com, Inc., 414 F.3d 400, 408-12 (2d Cir. 2005) (rejecting infringement claim based on pop-up advertisements).

63. 15 U.S.C. $\$ 1115$ (b) (4) (2000).

64. Dinwoodie \& Janis, supra note 1 , at 1616 .

65. See Armstrong Cork Co. v. World Carpets, Inc., 597 F.2d 496, 500 n.3 (5th Cir. 1979) (recognizing the statutory fair use provision as a codification of common law). Because the statutory fair use provision applies only to registered marks, courts have resorted to the common law to craft a fair use defense in the unfair-competition context. See Soweco, Inc. v. Shell Oil Co., 617 F.2d 1178, 1190 (5th Cir. 1980). As the court stated: 
to accept Dinwoodie and Janis's logic that codifying one defense excludes others in the same class would mean that courts were wrong to adopt the nominative use defense, one that Dinwoodie and Janis do not question. ${ }^{66}$

Contrary to Dinwoodie and Janis's charge, this form of common-law evolution of trademark doctrine is neither revolutionary nor unique. Indeed, common-law development has been at the heart of a wide variety of IP doctrines, from obviousness and the doctrine of equivalents in patent law to the idea-expression dichotomy and fair use in copyright law. ${ }^{67}$ Even in trademark, courts have long been willing to develop common-law limits and defenses to further the purposes of the law. ${ }^{68}$ That sort of common-law development is particularly appropriate in the Internet contexts in which trademark use issues have arisen because both the medium and the claims of trademark owners are new. The courts in the third-party liability cases, like the courts that historically dealt with claims based on comparative advertising and descriptive fair use, cannot avoid making new law because there is no directly applicable statutory provision to interpret. ${ }^{69}$ They will either recognize a new and unprecedented form of direct infringement

It would make no sense to characterize defendant's use as "fair" within the meaning of the Lanham Act for the purposes of a trademark infringement claim and at the same time characterize his use as "unfair" for the purpose of a section 43(a) unfair competition claim under the same statute.

Id. And at least some courts have used the descriptive fair use doctrine to excuse what are not really descriptive fair uses at all but rather non-trademark uses. See, e.g., Arnold v. ABC, Inc., No. 06 Civ. 1747(GBD), 2007 WL 210330, at*2-3 (S.D.N.Y. Jan. 29, 2007).

66. If the trademark use doctrine became a standard inquiry in every trademark case, including those involving defendants that sell their own products under the mark, then the trademark use doctrine might swallow subsidiary doctrines, including descriptive fair use. As discussed in this Article, however, trademark use has a more limited reach-covering only those who do not use the mark in branding their own goods or services-that does not tread into the territory of descriptive fair use. See also Int'l Stamp Art, Inc. v. U.S. Postal Serv., 456 F.3d 1270, 1274-75 (11th Cir. 2006) (analyzing the good-faith element of the descriptive fair use doctrine); Barrett, supra note 18, at n.433 (arguing that the two doctrines are distinct because descriptive fair use involves a subjective inquiry into good faith while trademark use is objective).

67. See, e.g., Baker v. Selden, 101 U.S. 99, 102-06 (1879) (establishing the idea-expression dichotomy); Winans v. Denmead, 56 U.S. (15 How.) 330, 343 (1854) (creating the doctrine of equivalents); Folsom v. Marsh, 9 F. Cas. 342, 348-49 (D. Mass. 1841) (establishing the fair use doctrine); Edmund W. Kitch, Graham v. John Deere Co.: New Standards for Patents, 1966 SuP. CT. REV. 293, 303-27 (tracing common-law evolution of the obviousness doctrine).

68. See, e.g., McDonald's Corp. v. Burger King Corp., 107 F. Supp. 2d 787, 791 (E.D. Mich. 2000) (noting the fair use doctrine's common-law roots); MCCARTHY, supra note 16, at $\$ 7: 63$ (discussing the long common-law history of the functionality doctrine, which Congress codified in 1998).

69. As we noted above, the closest statutory provision, the definition of "use in commerce," can be read to impose a requirement of trademark use, one that, if anything, is too strict. There is no way to read the statutory language to foreclose the imposition of such a requirement. 
claim, or they will recognize a doctrinal limitation that makes such a claim non-viable. Whichever road the courts choose, Congress has an opportunity to weigh in and reverse the courts' decision. To contend, as Dinwoodie and Janis do, that the trademark use doctrine not only diminishes the existing rights of trademark holders, but also deprives Congress of the opportunity to make reasoned policy in the regulation of trademarks on the Internet, ${ }^{70}$ is inaccurate and misleading.

In many ways, courts' adoption of a trademark use requirement to cabin third-party trademark claims resembles their response to third-party copyright claims in the Internet context. In the early- and mid-1990s, copyright holders asserted infringement claims against Internet service providers ("ISPs") based on content that users posted on the ISPs' servers. A handful of courts, reading the Copyright Act literally, ${ }^{71}$ had held that any unauthorized reproduction made by an ISP's server could subject the ISP to liability as a direct infringer, regardless of whether the ISP itself initiated the copy or had any knowledge of its nature. ${ }^{72}$ Others, however, found such an outcome incompatible with the history and doctrine of the Copyright Act. The seminal case, Religious Technology Center v. Netcom On-Line Communication Services, Inc., ${ }^{73}$ held that, "[a]lthough copyright is a strict liability statute, there should still be some element of volition or causation which is lacking where a defendant's system is merely used to create a copy by a third party." Despite the absence of any mention of "volition or causation" in the Copyright Act, the court found such requirements implicit in the statute's language and intent. ${ }^{75}$ Courts after Netcom uniformly endorsed its interpretation. $^{76}$

The Netcom analysis reflected a reasoned and contextual response to a new form of copyright claim. The approach does not entirely immunize ISPs from copyright liability because the common-law interpretation of the

70. Dinwoodie \& Janis, supra note 1, at 1659-60.

71. See 17 U.S.C. $\$ 106(1)$ (2000) (providing copyright holders with an exclusive right "to reproduce the copyrighted work in copies or phonorecords").

72. See Sega Enters. Ltd. v. MAPHIA, 857 F. Supp. 679, 686 (N.D. Cal. 1994); Playboy Enters., Inc. v. Frena, 839 F. Supp. 1552, 1559 (M.D. Fla. 1993) ("Intent or knowledge is not an element of infringement, and thus even an innocent infringer is liable for infringement.").

These courts also found defendants liable for infringing the rights of public distribution and display.

73. Religious Tech. Ctr. v. Netcom On-Line Commc'n, 907 F. Supp. 1361 (N.D. Cal. $1995)$.

74. Id. at 1370 .

75. Id.

76. See, e.g., CoStar Group, Inc. v. LoopNet, Inc., 373 F.3d 544, 549 (4th Cir. 2004) (endorsing Netcom, in which "the court grounded its ruling principally on its interpretation of $\S$ 106 of the Copyright Act as implying a requirement of 'volition or causation' by the purported infringer"). 
Copyright Act-like the Lanham Act—allows claims for contributory and vicarious infringement. ${ }^{77}$ By finding a volition requirement implicit in the Copyright Act, however, the Netcom court recognized a distinction between those who infringe directly and those whose liability, if any, turns on their relationship to another party's infringement. ${ }^{78}$ At the time, copyright holders protested-as Dinwoodie and Janis do in the trademark contextthat the Netcom approach had imported a new, non-statutory limitation on copyright owners and had insulated an entire economic sector from liability without congressional authorization. ${ }^{79}$ Congress, however, had a full opportunity to consider the copyright issue and, after hearing from all sides, passed a statute that largely replicated the Netcom result. ${ }^{80}$ Whatever happens with today's trademark use cases, Congress will undoubtedly have the same opportunity to make law in the trademark context. ${ }^{81}$

\section{DEFINITIONAL CONCERNS}

Because the notion of trademark use arises in two distinct contexts in trademark law, it makes sense to ask, as Dinwoodie and Janis do, whether the

77. The standards for secondary copyright liability are somewhat broader than trademark's contributory liability rule. Compare, e.g., A\&M Records, Inc. v. Napster, Inc., 239 F.3d 1004, 1019 (9th Cir. 2001) (holding that contributory copyright liability applies when one who has knowledge of another's infringement "induces, causes or materially contributes to"” that infringement (quoting Gershwin Publ'g Corp. v. Columbia Artists Mgmt., Inc., 443 F.2d 1159, 1162 (2d Cir. 1971))), and $i d$. at 1022 (noting that vicarious liability extends to defendants who enjoy a direct financial benefit from infringing activity that they have a right and ability to supervise), with Inwood Labs., Inc. v. Ives Labs., Inc., 456 U.S. 844, 854 (1982) (holding that contributory trademark infringement requires that a defendant actively induce infringement or continue to supply a product to a party with knowledge of that party's ongoing infringement). We use the copyright example not to suggest that trademark courts adopt the copyright standard but to illustrate the benefits of contextual, common-law responses to new uses and new technologies.

78. Religious Tech. Ctr., 907 F. Supp. at 1373-75.

79. See Bruce A. Lehman \& Ronald H. Brown, Intellectual Property and the NATIONAL INFORMATION INFRASTRUCTURE: THE REPORT OF THE WORKING GROUP ON INTELLECTUAL PROPERTY RighTS 14-15 (1995) (recommending adoption of direct liability for copyright infringement with no volitional exception).

80. Digital Millennium Copyright Act of 1998, Pub. L. No. 105-304, 112 Stat. 2860 (codified at 17 U.S.C. $\$ 512(2000)$ ).

81. It is worth noting that Congress has passed a somewhat similar safe harbor already in the trademark context. 15 U.S.C. § 1114(2)(B)-(C). This provision excludes the publisher of infringing content authored by another from liability for damages, or even from being enjoined if the injunction would require a change in the way the publisher does business or would delay publication of an issue. The language of the statute extends to Internet intermediaries as well, though it has rarely been applied in that context. This section is meant to exclude intermediaries from liability even where they actually publish the confusing advertisement, and so we think it is consistent with the tenor of our argument, though we acknowledge the contrary argument: like the descriptive fair use doctrine, statutory codification of a partial defense might be thought to exclude a fuller common-law defense. For the reasons we explained in the text, we reject that argument. 
term has a unitary meaning throughout the Lanham Act. Historically, the core battle over trademark use has involved the acquisition of trademark rights-i.e., whether the scale and duration of a party's use of a trademark is sufficient to vest that party with rights in the mark. ${ }^{82}$ Dinwoodie and Janis argue that recognizing a trademark use requirement in the infringement context will import all of the definitional problems that have plagued the doctrine in the rights-acquisition arena. ${ }^{83}$ We disagree, for two primary reasons.

First, the notion of trademark use has different purposes in the eligibility and infringement contexts and indeed focuses on different actors. In eligibility determinations, the trademark use doctrine prevents unwarranted enclosure of potential branding devices by requiring plaintiffs to establish some marketplace penetration before acquiring rights in a mark. ${ }^{84}$ Because of the importance of preserving a public domain of words and other sales devices, and because the point of trademark protection is to reduce consumer search costs, the trademark claimant bears a burden of establishing that its use as a mark is consistent and significant enough to vest it with trademark significance, such that its adoption by others could confuse consumers. Eligibility-related trademark use analysis therefore must resolve thorny questions about whether a defendant's use has the character and scope to establish the trademark as a brand, at least in the minds of some consumers. ${ }^{85}$

In the infringement context, by contrast, the trademark use doctrine need not resolve whether a defendant's use is sufficient to acquire brand significance in the minds of consumers. If a defendant is using a trademark in a deceptive product advertisement, that use can confuse consumers as to source or affiliation even if the defendant has never shipped a product bearing the mark. The trademark use doctrine in the infringement context serves a quite different objective: it avoids a chill on the speech and commercial activities of parties whose relationship to trademark infringement is, at best, indirect. ${ }^{86}$

82. See 15 U.S.C. $\$ 1051$ (requiring "use in commerce" as condition of federal registration).

83. Dinwoodie \& Janis, supra note 1 , at $1639-40$.

84. See Zazu Designs v. L'Oreal, S.A., 979 F.2d 499, 503 (7th Cir. 1992) (noting that the trademark use doctrine "prevents entrepreneurs from reserving brand names in order to make their rivals' marketing more costly").

85. For an example of those thorny issues, see Blue Bell, Inc. v. Farah Mfg. Co., 508 F.2d 1260, 1265-67 (5th Cir. 1975).

86. It bears emphasis that the trademark use doctrine does not necessarily insulate them from legal liability. Parties that play an intimate role in another party's infringement may well face liability as contributory infringers. Their liability, however, turns on proof that they satisfy the legal standard for contributory trademark infringement. 
Second, as a matter of statutory construction, the fact that the concept of trademark use arises in two different contexts in trademark law does not require that it have complete consistency in meaning. The Lanham Act contains a number of asymmetries in its treatment of eligibility issues and infringement ones; the trademark use doctrine is just one example. Use appears in numerous places in the Lanham Act, and its meaning in each turns on the context. Indeed, if complete consistency were required, Dinwoodie and Janis would have to concede that "use in commerce" for purposes of infringement analysis must be evaluated under the identical standard as it is for eligibility purposes, a result that would not only recreate the trademark use doctrine to which they object but, indeed, would define trademark use more narrowly than either we or the courts have done. ${ }^{87}$

We agree with Dinwoodie and Janis that the scope of use sufficient to establish a trademark as a source-identifier in the minds of the public is greater than the scope of use sufficient to tamper with that role and thus commit infringement. We do not, however, believe that this asymmetry provides reason enough to abandon the trademark use requirement in the infringement context.

\section{Policy REASOnS For Maintaining The Direct/Indirect Distinction}

Even if trademark use were not well grounded in history, that would be no reason for courts to hold back from adopting the doctrine now. A trademark use requirement is both necessary and appropriate to keep trademark law true to its core mission of protecting consumers by improving the quality of information in the marketplace. In the absence of an express statutory bar to a trademark use requirement-something even Dinwoodie and Janis don't suggest exists in the statute-courts have the power and should have the motivation to protect defendants from expansive new theories of trademark liability.

What exactly is wrong with abandoning trademark use and just relying on the likelihood-of-confusion test, as Dinwoodie and Janis suggest? We see several problems with such an approach.

The Threat to Legitimate Uses of Marks. For one thing, at least with respect to intermediary claims, eliminating a trademark use requirement would prevent a whole host of uses that courts and Congress have explicitly declared legal. If courts were to dispense with the requirement of trademark use, they would create a form of strict liability against intermediaries by allowing claims for direct rather than contributory infringement. Dinwoodie

87. That section of the Lanham Act defines "use in commerce" as "the bona fide use of a mark in the ordinary course of trade, and not merely to reserve a right in a mark." 15 U.S.C. § 1127. Specifically, that use requires that the mark be "placed in any manner on the goods or their containers or the displays associated therewith" and that "the goods are sold or transported in commerce." Id. \$1127. 
and Janis implicitly endorse this liability in the search-engine context: any time an advertiser places a confusing keyword-based ad, they suggest, the search engine should face liability as a direct infringer. ${ }^{88}$ Indeed, the logical upshot of their analysis is that trademark holders can prevent any unauthorized use of their mark to generate ads if they can produce a survey suggesting that some consumers think such ads are generally approved or sponsored by the trademark holder. ${ }^{89}$ Both of these forms of liability, however, threaten speech that trademark law has always explicitly encouraged and indeed run counter to the very contextualism that Dinwoodie and Janis otherwise celebrate.

We start with the broadest version of liability. If, as the Playboy $v$. Netscape opinion suggests ${ }^{90}$ plaintiffs can win trademark cases merely by showing that some people are confused by the very idea of keyword-based ads, ${ }^{91}$ then trademark holders can prohibit all unauthorized use of their marks to generate advertisements. But this would impede a whole universe of uses that trademark law allows because they serve its core information-facilitating goals. Sellers of Frigidaire-compatible refrigerator parts clearly have the right to use the Frigidaire name on the packaging and advertising of their products. ${ }^{92}$ In the pre-Internet world, such sellers also had the ability to use consumer-generated trademark signals to call attention to their products. A consumer who walked into an appliance store and inquired about Frigidaire parts could be directed to both the branded and the unbranded versions. To

88. Dinwoodie \& Janis, supra note 1, at 1604-05.

89. Playboy introduced such a survey in the Playboy $v$. Netscape case, and the Ninth Circuit used it as the basis for concluding that Netscape may well have committed trademark infringement by allowing keyword-based ads using the Playboy marks. See Playboy Enters., Inc. v. Netscape Commc'ns Corp., 354 F.3d 1020, 1026 (9th Cir. 2004) (noting an expert report that "concluded that a statistically significant number of Internet users searching for the terms 'playboy' and 'playmate' would think that PEI, or an affiliate, sponsored banner ads containing adult content that appear on the search results page"). But see Goldman, supra note 7, at 577 \& n.285 (describing the Playboy survey as "flawed beyond repair").

The Ninth Circuit recently rejected the idea that any use of keywords that causes a competitor's ad to appear next to a search result is illegal. Picture It Sold, Inc. v. iSOLDIT, LLC, No. 06-15112, 2006 WL 2467552, at*1 n.3 (9th Cir. Aug. 28, 2006). That case involved keywords purchased on words that appeared in the plaintiff's mark but not on the entire mark itself.

90. Playboy, 354 F.3d at 1026-27 ("The [expert study Playboy introduced] establishes a high likelihood of initial interest confusion . . . among consumers . . ..”).

91. In Playboy, the plaintiff introduced a survey suggesting that some people believed that trademark holders sponsored every ad that appeared in response to a trademark-based search. $I d$. at 1026. The court used this survey as the basis for concluding that keyword-based ads were likely to confuse the public and that Netscape could face liability for enabling them. See id. at 1026, 1031.

92. These sellers cannot use logos and other forms of the mark on their ads and packaging that might suggest an official relationship between themselves and the trademark holder, but they can clearly use the trademark in plain text to describe the nature of their product. 
deprive Frigidaire competitors of the equivalent opportunity in the online context would severely impede competition, particularly in markets dominated by a few strong brands. ${ }^{93}$

Perhaps Dinwoodie and Janis do not intend to go this far and would allow intermediaries to sell certain trademark-triggered ads of the sort that trademark law has traditionally exempted from liability. Accepting that conclusion, however, amounts to acknowledgement of the distinction between direct and indirect infringement. If some unauthorized keywordbased ads are legitimate and others are confusing, then the wrong in the latter case occurs not in the act of selling keywords that signal information to consumers, but in placing an ad that deceives those consumers. The viability of a trademark claim, in other words, turns on the context of the advertiser's statements and status rather than that of the intermediary. The intermediary's use of the mark bears a relationship to the ad and, in fact, plays a causal link in enabling the advertiser to infringe; but its mere sale of the keyword, without more, is an entirely neutral act that can lead to either infringing or non-infringing use by its advertisers.

When viewed in this way, the rationale for divorcing direct and indirect infringement comes into stark relief. Trademark law, like patent and copyright law, ${ }^{94}$ has always resisted direct liability against parties whose products or behavior can be used by others for both good and ill. Generic pharmaceutical manufacturers that produce look-alike drugs may well, through their design choices, tempt pharmacists to pass the generic version off as the branded product. ${ }^{95}$ To fault them for creating that temptation,

93. The same concerns apply to other lawful uses of trademarks, including descriptive fair use, nominative fair use, comparative advertising, and advertising of used and reconditioned products. A rule forbidding the use of trademark-based signals by advertisers would inhibit all of these desirable, information-enhancing uses of marks.

94. See, e.g., 35 U.S.C. $\$ 271$ (b)-(c) (2000) (limiting contributory patent liability to (1) those who induce infringement and (2) those who sell devices specially designed or adapted to commit infringement, if such devices are "not a staple article or commodity of commerce suitable for substantial infringing use"); Sony Corp. v. Universal City Studios, Inc., 464 U.S. 417, 440-42 (1984) (adopting the "staple article of commerce" doctrine in copyright law). Indeed, the Supreme Court in Sony made clear that the scope of indirect liability in trademark law is narrower than the corresponding doctrines in copyright and patent law. See id. at $439 \&$ n.19. The Court stated:

If Inwood's narrow standard for contributory trademark infringement governed here, respondents' claim of contributory infringement would merit little discussion. Sony certainly does not 'intentionally induce[ ]' its customers to make infringing uses of respondents' copyrights, nor does it supply its products to identified individuals known by it to be engaging in continuing infringement of respondents' copyrights.

Id.

95. Inwood Labs., Inc. v. Ives Labs., Inc., 456 U.S. 844, 861-62 (1982) (White, J., concurring). 
however, would deprive the public of the significant benefit that look-alike generics bring about when accurately packaged and truthfully disclosed. ${ }^{96}$ Conceivably, the manufacturer could aggressively police its retailers to try to protect against passing off in every instance. But the law does not require it do so. Instead, it imposes liability only when the manufacturer continues to provide the product to retailers after acquiring specific knowledge of their individual acts of infringement. ${ }^{97}$ To cast the net any wider would cause waste and inefficiency; manufacturers would either overspend on enforcement, redesign their products in suboptimal ways, or curtail the scope of their sales to avoid the risk of strict liability.

The rationale for the direct/indirect distinction applies with equal force to informational intermediaries. They, like the generic manufacturer in Inwood, ${ }^{98}$ offer a service that may tempt some individuals to infringe but that also has legitimate and desirable applications. Search engines, like generic manufacturers, may face liability if they actively induce infringement. ${ }^{99}$ To treat these intermediaries as strictly liable for every infringing use of their service, however, would not only transform trademark doctrine but would also impose exactly the type of drag on lawful commerce that the direct/indirect infringement dichotomy seeks to avoid.

The Confusion over Confusion. Beyond these concerns about overbreadth, there is another, more fundamental, problem with dispensing with a trademark use requirement: the likelihood-of-confusion standard itself is both substantively and procedurally ill-suited to resolve the complex set of issues raised by today's novel trademark claims. We see at least four specific reasons to resist exclusive reliance on likelihood of confusion.

First, the likelihood-of-confusion test is, at base, circular. In part, this stems from the very reactive nature of the test that Dinwoodie and Janis celebrate. Whether a particular use confuses consumers depends, in part, on the legal baselines that trademark law sets. And as Barton Beebe's empirical

96. See id. ("Preventing the use of generic drugs of the same color to which customers had become accustomed in their prior use of the brand name product interferes with the important state policy, expressed in New York and 47 other States, of promoting the substitution of generic formulations."); $c f$. $i d$. at 861 ("The mere fact that a generic drug company can anticipate that some illegal substitution will occur to some unspecified extent, and by some unknown pharmacists, should not by itself be a predicate for contributory liability.").

97. Id.; cf. MCCARTHY, supra note 16 , at $\$ 25: 18$ (stating that "the supplier's duty does not go so far as to require him to refuse to sell to dealers who merely might pass off its goods").

98. Inwood Labs., Inc. v. Ives Labs., Inc., 456 U.S. 844 (1982).

99. Contributory infringement has historically required either inducement or the supply of goods to counterfeiters knowing they would be used to infringe; the supply of services has not historically constituted contributory trademark infringement. It is possible that courts will extend the doctrine to the supply of services, but given the narrow scope of contributory infringement in the trademark context, courts should approach such an extension with caution and apply it only against defendants with a high level of complicity in the direct infringer's behavior. 
work has shown, as a practical matter, the multifactor likelihood-of-confusion test collapses into only two considerations-the similarity of the marks and the defendant's intent in adopting the mark. ${ }^{100}$ By hypothesis, non-trademark uses often involve the identical mark. This is because the defendant employs the mark itself either as a signal of consumer preferences or to refer to the trademark or something that it represents. This means that not only must defendants go to trial to defend their nontrademark uses, but their likelihood of winning depends almost entirely on a single subjective criterion-the fact finder's view of the defendant's intent. And intent is entirely manipulable. ${ }^{101}$ The trademark owners that have succeeded in holding defendants liable for non-trademark uses have done so by claiming that the defendant engaged in "free riding." 102 But permissible free riding is everywhere. ${ }^{103}$ Since we lack any normative baseline for defining what forms of free riding should be forbidden, the likelihood-of-confusion test standing alone cannot establish any limits on the ability of trademark owners to forbid a new category of uses.

We can demonstrate this point with a seemingly extreme example. Most everyone would presumably agree that a grocery store should be allowed to locate generic colas on a shelf next to Coca-Cola. ${ }^{104}$ But why? One would say, perhaps, that such uses do not confuse consumers into thinking that Coke licenses the placement or sponsors the generic colas. But if consumers are not confused about sponsorship, it is only because the law has long permitted such uses, and so consumers accept and understand them. That is not an inevitable result, however. Had the courts said at the outset that trademark owners could sue to prevent such placement-reasoning that consumers might think that proximity implied association and diverted

100. Beebe, supra note 30 , at 1623-31.

101. Nor is actual confusion, another factor that seems like it should be quite important, immune from the possibility of manipulation. In Anheuser-Busch, Inc. v. Balducci Publications, 28 F.3d 769 (8th Cir. 1994), for example, the court found an obvious parody of a beer ad to be confusing, in part because the plaintiff's survey expert tweaked the questions asked of consumers in a way that generated spurious evidence of confusion. Id. at 775 .

102. Edina Realty, Inc. v. TheMLSonline.com, No. Civ. 04-4371JRTFLN, 2006 WL 737064, at *1-2 (D. Minn. 2006); 1-800 Contacts, Inc. v. WhenU.com, Inc., 309 F. Supp. 2d 467, 490 (S.D.N.Y. 2003), rev'd, 414 F.3d 400 (2d Cir. 2005).

103. Wendy J. Gordon, On Owning Information: Intellectual Property and the Restitutionary Impulse, 78 VA. L. REV. 149, 167-69 (1992) ("A culture could not exist if all free riding were prohibited within it."); Mark A. Lemley, Property, Intellectual Property, and Free Riding, 83 TEx. L. REV. 1031, 1049 (2005).

104. Dinwoodie and Janis actually suggest in their Article that proximate placement may indeed be confusing, so perhaps they think that such placement should be enjoined or at least that trademark owners should get to trial on such a claim. See Dinwoodie \& Janis, supra note 1, at $1635 \&$ n.177 and accompanying text. We think the prospect that Dinwoodie and Janis's approach might lead to successful trademark suits against grocery stores for putting all the sodas together on the same aisle is an excellent reason to reject their approach. 
sales, as evidenced by the fact that product sellers pay grocery store owners for shelf placement-one can easily imagine a world in which grocery stores had to separate like products to avoid any risk of association. Further, even if a finding of confusion seemed unlikely, many companies would agree to change their behavior or take a license rather than pay to litigate a case all the way to trial and risk losing. This, in turn, would mean that consumers would not be used to seeing all the colas grouped together and would make it harder for anyone else to make such a use because, over time, the placement of generic cola beside Coke would be more surprising to consumers. And if no one else is putting generic colas next to Coke, it is an easy mental step to conclude that a grocer that does so is free riding on Coke's interest in being insulated from nearby competitors, particularly if the grocer is making money directly or indirectly from the placement or sales of generic colas. ${ }^{105}$

Arguably, something similar has already happened with t-shirts bearing university and sports logos. A use that originally confused no one came, over time, to confuse consumers as a few courts held that such uses were illegal. These rulings led to widespread licensing, which made consumers assume that such t-shirts came only from licensed vendors. ${ }^{106}$ That is, indeed, precisely the world trademark owners seek to impose in the Internet context by suing search engines.

Second, because of its fact-specificity, the likelihood-of-confusion test is ill-suited to early resolution of lawsuits. Trademark owners are asserting claims of a sort they never have before: against the media, book publishers, movie and television creators, search engines, comparative advertisers, critics, and parodists. And they are asserting them in droves. ${ }^{107}$ Even if, in theory, we could weed out all of these claims at trial using the likelihood-of-confusion test, doing so would be costly and uncertain. Defendants who choose to fight these new claims will face years of uncertainty and hundreds of thousands of dollars per case. ${ }^{108}$ And winning will buy them very little because the next plaintiff is always free to try again to concoct a survey under which consumers will be confused-or to find a

105. For a more detailed analysis of the retailer issue and an argument that Internet intermediaries play the same role for trademark purposes as retailers, see Eric Goldman, Brand Spillovers (Aug. 3, 2006) (unpublished manuscript), available at http://www.law.berkeley. edu/institutes/bclt/ipsc/papers2/goldman.pdf.

106. See Dogan \& Lemley, supra note 52, at 461-65 (detailing this history).

107. Our conversations with search-engine lawyers suggest that they get literally thousands of keyword-based trademark threats every year in the United States alone.

108. The AIPLA's economic survey reports that the median expenditures per side in legal fees to litigate a trademark case to trial were $\$ 300,000$ for a small case, $\$ 700,000$ for a mediumsized case, and $\$ 1.25$ million for a large case. AMERICAN INTELlECtUAL Property LAW ASSOCIATION, REPORT OF THE ECONOMIC SURVEY 22 (2005). 
judge more sympathetic to its complaint of free riding. Creating a doctrine that can be applied pretrial to short-circuit such dubious new claims seems like a good idea to us.

Third, and more insidious, is the combination of these two factors. Because it would be costly and uncertain to litigate all of the cases to trial, many people who have the right to make a use may give in rather than fight to protect their rights. Despite inconclusive legal results so far, keyword suits have already caused Yahoo! to pull all comparative, critical, and independent-vendor ads keyed to trademarks; Google has adopted a policy forbidding even such legitimate ads from using the trademark in the ad text. ${ }^{109}$ Without the trademark use doctrine, we may soon be in a world in which anyone who searches online will find only ads approved by the trademark owner. That, in turn, may actually affect consumer perceptions of whether such uses are permissible at all, a process Sara Stadler has called "spiralarity." ${ }^{110}$ Then trademark owners will start in on not just ads but also search results, seeking to ensure that their site appears first-or even exclusively-on the search-results list. ${ }^{111}$ If trademark owners prevail, eventually consumers may well be confused if they see any reference to a trademark not pre-approved by the trademark owner. But both social

109. Kevin Newcomb, Yahoo! Modifies Trademark Keyword Policy, ClickZ News, Feb. 24, 2006, available at http:/ /www.clickz.com/showPage.html?page=3587316.

110. As Stadler argues, risk aversion leads to ever-expanding rights over time because if companies are unwilling to make questionable uses, it entrenches as the norm-and therefore the outer limits of legality-behavior that was designed to fall well within those outer bounds. Sara K. Stadler, Incentives and Expectation in Copyright, 58 HASTINGS L.J. (forthcoming 2007) (manuscript at 22), available at http://ssrn.com/abstract=889344 ("When legal rules define rights by reference to the expectations of rightsholders, lawmakers can use those rules to narrow rights by conditioning rightsholders to lower their expectations."); James Gibson, Risk Aversion and Rights Accretion in Intellectual Property Law, 116 YALE L.J. 882 (2007) (same). For arguments that the scope of confusion is, in fact, broadening over time, see, e.g., Robert G. Bone, Hunting Goodwill: A History of the Concept of Goodwill in Trademark Law, 86 B.U. L. REV. 547, 606-14 (2006); Rochelle Cooper Dreyfuss, Reconciling Trademark Rights and Expressive Values: How to Stop Worrying and Learn to Love Ambiguity, in TRADEMARK LAW AND THEORY: A HANDBOOK OF ConTEMPORARY RESEARCH (Graeme B. Dinwoodie \& Mark D. Janis eds., forthcoming 2007), available at http://ssrn.com/abstract=929534; Lemley, supra note 6, at 1697-1713.

111. Our communications with search-engine representatives indicate that they already receive many complaints demanding not only the removal of ads but also "clean" search results. Even scholars have started to suggest that search engines should be required to manipulate their search algorithms so that trademark owners show up first, or at least get a special note pointing consumers to their official website. See Frank Pasquale, Rankings, Reductionism, and Responsibility, passim (Seton Hall Univ. Sch. of Law, Working Paper No. 888327, 2006), available at http://papers.ssrn.com/sol3/papers.cfm?abstract_id=888327. But see Goldman, supra note 7, passim (contending that overly restrictive trademark law will harm consumer interest in access to information online). 
discourse and commerce would be the worse for it. ${ }^{112}$ Parodies, reviews, and advertising of competing and complementary products serve the purposes of trademark law. They give consumers information about a productinformation they are unlikely to get from the trademark owner in many cases. But without the protection for such uses that trademark use doctrines provide, consumers will never have the opportunity to see such information.

Finally, even if we were persuaded that some consumers might be confused by the very fact of juxtaposition of products or ads on the Internet or on a store shelf, we would likely still oppose liability for those uses. The confusion test is designed to reduce consumer search costs by making sure that consumers are not misled in the marketplace. ${ }^{113}$ But the ultimate purpose of reducing consumer search costs is to facilitate the operation of that marketplace. If trademark law interferes with competition, trademark law must give way, or it will end up destroying the village in order to save it. As the Eighth Circuit has put it, "By the very nature of a trademark action, the value placed on free competition must be weighed against any

112. See generally Goldman, supra note 7 (explaining the benefits of a robust market in search relevance).

113. See Ty Inc. v. Perryman, 306 F.3d 509, 510 (7th Cir. 2002) ("The fundamental purpose of a trademark is to reduce consumer search costs by providing a concise and unequivocal identifier of the particular source of particular goods."); WILLIAM M. LANDES \& RICHARD A. POSNer, The ECONOMic Structure OF INTELlectual Property LAW 167-68 (2003); Nicholas S. Economides, The Economics of Trademarks, 78 TRADEMARK REP. 523, 525-27 (1988) (discussing the economic benefits of marks that apprise consumers of products' unobservable features); Nicholas S. Economides, Trademarks, in 3 THE New PALgRaVE Dictionary of ECONOMiCS AND THE LAW 602 (Peter Newman ed., 1998) [hereinafter Economides, Trademarks] (describing the savings for consumers in product searches as one of " $[t]$ he primary reasons for the existence and protection of trademarks"); Brian A. Jacobs, Trademark Dilution on the Constitutional Edge, 104 Colum. L. REV. 161, 164 (2004) (noting the search-costs rationale); William M. Landes \& Richard A. Posner, Trademark Law: An Economic Perspective, 30 J.L. \& ECON. 265, 268-70 (1987) (identifying the lowering of brand-recognition costs to consumers as the justification for trademark law); Lemley, supra note 6, at 1690-94 (describing economic justifications for trademarks and advertising); I.P.L. Png \& David Reitman, Why Are Some Products Branded and Others Not?, 38 J.L. \& ECON. 207, 208-11, 218 (1995) (analyzing empirical search cost data and suggesting that "consumers of products subject to performance uncertainty will pay for brandname assurance"); John F. Coverdale, Comment, Trademarks and Generic Words: An Effect-onCompetition Test, 51 U. CHI. L. REv. 868, 869-70 (1984) (noting that trademark law encourages competition, which potentially decreases the cost to consumers); see also Qualitex Co. v. Jacobson Prods. Co., 514 U.S. 159, 163-64 (1995) (explaining that trademark law "reduce[s] the customer's costs of shopping and making purchasing decisions," and "helps assure a producer that it (and not an imitating competitor) will reap the financial, reputation-related rewards associated with a desirable product" (internal quotations omitted) (alteration in original)); Union Nat'l Bank of Tex., Laredo v. Union Nat'l Bank of Tex., Austin, 909 F.2d 839, 844 (5th Cir. 1990) ("The idea is that trademarks are 'distinguishing' features which lower consumer search costs and encourage higher quality production by discouraging free-riders."); cf. Mishawaka Rubber \& Woolen Mfg. Co. v. S.S. Kresge Co., 316 U.S. 203, 205 (1942) ("A trademark is a merchandising short-cut which induces a purchaser to select what he wants, or what he has been led to believe he wants."). 
individual's property interest in that trademark, so that the analytic focus should also be on the consumer's ability to obtain the lowest price goods." 114 That is why trademark law provides only very limited protection to product configurations, as we have explained elsewhere. ${ }^{115}$ And it is why courts have traditionally been reluctant to extend liability to intermediaries that offer "dual use" goods or services capable of legitimate as well as infringing uses. ${ }^{116}$ Preventing intermediaries from communicating accurate information to consumers interested in that information, or stores or shopping malls from grouping competitive products together, does sufficient harm to a free market that we think society should be willing to tolerate even a substantial amount of confusion rather than countenance that harm.

$* * * * * * * * * * * * * *$

We do not suggest (as Dinwoodie and Janis claim) that trademark law abandon confusion as the touchstone of a trademark claim. To the contrary, the heart of most trademark suits will remain the question of whether the defendant's use creates a likelihood of confusion as to the source, sponsorship, or affiliation between the trademark holder and the defendant's products or services. Confusion is the basic question in trademark law. But it is not the only question. Trademark law has a variety of requirements and defenses, all of which necessarily reflect the view that sometimes we should tolerate some risk of confusion, either in the service of some other goal or because the potential harm from allowing a class of claims outweighs the harms from possible confusion. The trademark use doctrine fits easily in that basic framework. Rather than displacing the likelihood-of-confusion analysis, the trademark use doctrine provides a critical threshold requirement that reaffirms the traditional, and rightful, focus of trademark law. It provides, in other words, some normative boundaries within which the likelihood-of-confusion doctrine can operate.

\section{CONCERNS}

Dinwoodie and Janis have raised a number of concerns about the trademark use doctrine. While a few of their concerns may argue against an expansive approach to trademark use, none of them justifies rejection of the

114. See Calvin Klein Cosmetics Corp. v. Lenox Labs., Inc., 815 F.2d 500, 505 (8th Cir. 1987).

115. See generally Dogan \& Lemley, supra note 20.

116. See, e.g., Sony Corp. v. Universal City Studios, Inc., 464 U.S. 417, 440-42 (1984); see also Mark A. Lemley \& R. Anthony Reese, Reducing Digital Copyright Infringement Without Restricting Innovation, 56 STAN. L. REV. 1345, 1379-90 (2004). 
more surgical form of the doctrine that we discuss in this paper. In this section, we briefly address their specific concerns.

Is Trademark Use Too Limiting? First, Dinwoodie and Janis worry that a trademark use doctrine will have a ripple effect beyond the Internet context and into other areas of trademark law. They characterize the trademark use doctrine as overkill, as a blunt instrument for addressing a problem that calls for a surgical solution. But the examples that they offer to illustrate the dangers of the trademark use doctrine-merchandising and product configurations-strike us as red herrings.

We have argued elsewhere against a presumptive right of trademark holders to control the sale of merchandise bearing their marks. ${ }^{117}$ Our argument, however, has focused primarily on the fact that we doubt that the use of trademarks on merchandise historically confused consumers, and yet courts have recognized merchandising rights without even posing the confusion question. Our critique of the merchandising cases has focused not on trademark use but on the dearth of assessment under the appropriate likelihood-of-confusion standard. Certainly, if some unauthorized party sells shirts or shoes emblazoned with the Nike swoosh or the JUST DO IT logo, she is engaged in both trademark use and infringement: she has used Nike's trademark as a device to sell her own product and has done so in a way that is likely to confuse the relevant public about the source of that product. But in other contexts, the sale of merchandise bearing a mark may do nothing to suggest source or sponsorship, much less to confuse people. These claims should fail under a likelihood-of-confusion approach. ${ }^{118}$

The other example raised by Dinwoodie and Janis, protection of product configuration trade dress, militates in favor of, rather than against, the trademark use doctrine. If a party adopts its competitor's protected, nonfunctional product configuration in a way that confuses potential customers over source, sponsorship, or affiliation, it is engaged in a trademark use of that trade dress. The key question in trademark use cases is whether defendants have used the mark in a way that suggests something about the source or sponsorship of their own products or services. If they have not, using trade dress theory to protect product configuration is precisely the sort of misuse of the doctrine to interfere with competition that the Supreme Court warned against in Wal-Mart v. Samara Brothers and TrafFix

117. See generally Dogan \& Lemley, supra note 52.

118. We concede that many consumers may have developed an assumption of trademark-holder sponsorship of merchandise, particularly in the professional sports context. Because this assumption arguably resulted from erroneous decisions in early merchandising cases, however, we suggest that courts should consider ways to correct the perception by allowing relief short of an injunction when confusion is likely but rectifiable. 
Devices v. Marketing Displays. ${ }^{119}$ We see no reason why the trademark use standard should narrow or eliminate legitimate protection against infringing uses of marks in either the merchandising or product-configuration context. Rather, it helps prevent the expansion of trademark law into areas where it has no legitimate basis. That is a feature of the trademark use doctrine, not a bug.

Information Overload. Dinwoodie and Janis suggest that the search-costs approach to trademark law may have it wrong in viewing more information as an unqualified good. If trademark law is too permissive in allowing unauthorized uses of marks, they argue, informational overload will inevitably result. ${ }^{120}$ While this argument has some initial intuitive appeal, it quickly breaks down under scrutiny. At root, the information-overload argument assumes that the quality of information will improve if trademark holders are allowed to control all uses of their marks, as signals of consumer preferences or otherwise. This assumption is wrong for three related reasons.

First, while more information is not always better, neither is less. Indeed, basic market economics tells us that transparent markets with perfect information will bring about the best products and lowest prices for consumers. Perfect information, of course, is unachievable in most markets, but the basic instinct of market economics-that consumers will do better if they have accurate information about the full range of product offerings and characteristics-rings true even in the imperfect markets of the real world.

Second, if trademark law's goal is to improve the overall quality (not necessarily quantity) of information available to consumers, giving trademark holders unfettered control over their marks will impede rather than promote that objective. Trademark holders often have no incentive to inform consumers about compatible, complementary, or competing products in which the consumers may well have an interest, or about negative reviews or price comparisons featuring their own products. Informational intermediaries, on the other hand, have a tremendous incentive to give consumers the information that might interest them. ${ }^{121}$

119. TrafFix Devices, Inc. v. Marketing Displays, Inc., 532 U.S. 23, 29-35 (2001) (denying trademark protection for a previously patented feature and noting that "copying is not always discouraged or disfavored by the laws which preserve our competitive economy"); Wal-Mart Stores, Inc. v. Samara Bros., Inc., 529 U.S. 205, 213-14 (2000) (concluding that "[c]onsumers should not be deprived of the benefits of competition with regard to the utilitarian and esthetic purposes that product design ordinarily serves").

120. Dinwoodie \& Janis, supra note 1, at 1627-30.

121. See, e.g., Goldman, supra note 7, at 511-28; Frank A. Pasquale III, The Law and Economics of Information Overload Externalities, http://papers.ssrn.com/sol3/papers.cfm?abstract _id $=888410$ (arguing in the copyright context that the law should treat information intermediaries such as search engines more favorably because, if unfettered, they can help solve the information-overload problem). 
Logic suggests that these intermediaries will have an interest in not swamping their users with irrelevant information. ${ }^{122}$

Finally, if information overload is a serious concern, an aggressive approach under trademark law may well exacerbate the problem rather than solve it. Trademark-based searches can provide quite specific signals about consumers' personal preferences and characteristics. If advertisers can use these signals to target potential customers, they can advertise selectively, targeting customers most likely to have an interest in their products. Depriving advertisers of these trademark-based signals will not stop them from advertising; it will simply eliminate one of their tools for accurately targeting potential customers. Without this tool, online advertising may well become more generalized, with consumers suffering more ads that bear no relationship to them or their preferences. Indeed, it is the success of this targeting mechanism relative to the broadcast and newspaper advertisements of the past that has single-handedly driven the extraordinary economic growth of search engines in this decade.

The Risk of Under-Regulation. Finally, Dinwoodie and Janis warn of the dangers of leaving an entire area of commerce essentially unregulated under trademark law. The trademark use doctrine, however, does not leave trademark holders without a remedy against confusing uses of their marks online. To the contrary, trademark holders have the same remedies they have always had: they may sue the advertisers themselves if the advertisers are using the mark in a way that confuses consumers as to the source or sponsorship of their products. They may also be able to proceed under traditional standards of contributory infringement against an intermediary whose business model appears calculated to induce infringement. Unless the passage of time suggests that this model is not working in the new, online context, courts could resist the temptation to restructure the relationship between direct and indirect infringers in trademark law.

\section{CONCLUSION}

The trademark use doctrine has always played a central-albeit implicit-role in trademark law. Rather than a figment of the imagination, the doctrine is an essential tool for maintaining the integrity of trademark law.

122. A logical implication of Dinwoodie and Janis's approach to trademark law might well be to subject search engines to liability if trademark holders do not like their placement in search results, even absent any paid placement. Without any knowledge or intent requirement, or for that matter any other limit on what can constitute "trademark use," a search engine could well infringe if its search algorithm happened to bring up a search result that confused some consumers. 